\title{
A patentometric assessment of selected R\&D priority areas in South Africa, a comparison with other BRICS countries
}

\author{
Xolani Makhoba ${ }^{1}$ \\ Email: xolani100@gmail.com \\ Anastassios Pouris \\ Email: anastassios.pouris@up.ac.za
}

Affiliation: Institute for Technological Innovation, Graduate School of Technology Management, Department of Engineering and Technology Management, University of Pretoria, Pretoria 0002, South Africa

\begin{abstract}
This study assessed the inventive activity through patents registered by South African researchers worldwide using the WIPO database. South Africa is the most prolific producer of patents in the African continent. In this study, the focus was on research priority areas documented in the South African government policy documents rather than the overall inventive output of the country. The research priority areas considered were ICT, nanotechnology, biotechnology, climate change, energy and health. Patents in the areas were compared with the BRICS (Brazil, Russia, India, China and South Africa) countries and Egypt. The comparison was done using the revealed technological advantage sometimes referred to as the specialisation index. It is found that the two African countries have not increased their patent share significantly and are yet to find their specialisation. It was found that while South Africa is doing well in terms of patenting compared to other developing countries, the profile of inventions being patented are not necessarily aligned with the priority areas as documented in government policy.
\end{abstract}

\section{Keywords:}

Patents, R\&D priority areas, South Africa, BRICS, specialisation index

\footnotetext{
${ }^{1}$ Corresponding authour
} 


\section{Introduction}

South Africa is the biggest producer of patents and publications in the African continent; it is therefore in a unique position among this group of developing countries. The output in terms of publication from this country comprises a third of all publications produced from the African continent [1]. Publications are widely used as a measure of R\&D performance of countries; however, when it comes to innovation the picture is not as obvious. Technological innovation is now accepted to be a major factor behind economic development and competitiveness for individual firms, regions, and nations [2]. In measuring innovation, one has a choice between considering at the input indicators or output indicators. There are two most commonly used indirect methods that serve as proxy for innovation, these are R\&D investments, which is an input indicator in the innovation process, as well as the patent data, which is an output indicator of innovative activity [3]. The measurement of innovation is an issue that has been studied quite extensively with most studies correlating investments in innovation to financial wellness. However, patents have also been used to indicate the level of progress towards innovations and in this study, the progress of development of country's R\&D priority areas is assessed using patents. Patents are used due to the extensive availability of information across countries and regions. In addition, patents are an indispensable tool in the protection of intellectual property particularly within the context of a knowledge intensive economy. This is important since a patent by definition according to the EPO is a legal title of industrial property granting its owner the exclusive right to exploit an invention commercially for a limited area and time. The patent therefore gives the inventor the right to stop others from, among other things, copying, using or selling such invention without authorisation. In return for the exclusive right to exploit it, the technical details of the invention are published. Novelty, inventiveness and industrial applicability of the invention needs to be demonstrated for a patent to be granted. It is important to note that a granted patent does not necessarily mean the product is safe for consumers use, for example the medicines still have to undergo the medical trials and approvals and proven safe for use before they can be made available in the market.

South African performance in relation to its strategic priority areas in science and technology is poorly understood. The strategic priority areas discussed in this paper refer to areas that government has identified as deserving special attention and funding with the aim of stimulating industrial development. Therefore, the purpose of this paper is to evaluate research performance 
in the selected priority areas from a quantitative perspective using patent data. The focus is on the performance of South African based research institutions and inventors in priority areas such as ICT, nanotechnology, biotechnology, energy and health. While no vibrant domestic industry exist in most of these areas, the government aims to use its expenditures in public research institutes to stimulate innovation in these areas resulting in nascent economic activity. It is worth mentioning that the country has other science priority areas which by their very nature do not necessarily produce much patents; these include areas such as human sciences and palaeontology. There are also areas that are poorly defined or too broad to be measurable, such as technology and innovation for poverty reduction. As a result, this study will only consider those areas that are more readily patentable and will not provide a complete coverage of technology as envisaged in the R\&D strategy. A comprehensive list is contained in the Ten Year Innovation Plan [4] as well as other sector specific strategies of the country's National Department of Science and Technology. The bioeconomy and biotechnology through the 'Farmer to Pharma' concept, space and space technology, energy, climate change and environment are the areas that are mentioned as important in the country's Research and Development Strategy [5].

The use of patent data to measure innovation has its shortcomings, as patents are not always representative of commercially exploited innovation. However, the traditional role of patents is to provide inventors with an opportunity to recoup and profit from their inventions by providing them with a temporary monopoly to commercialise their research findings [6]. Therefore, it is likely that inventors will likely patent those inventions they deem to have a better chance of commercialisation. Based on this it is evident that patents are more representative of an input into the innovation rather than an output evidence of it, meaning that patents are just one of the inputs in the innovation value chain [7]. Regardless of this, it is well established that patent data is still a useful proxy for measuring progress in innovations and has been used extensively for this purpose [8-10]. Studies by Griliches [11] suggested that there is a strong correlation between R\&D expenditures and increased patenting activity. More importantly, a recent study looking at the BRICS (Brazil, Russia, India, China and South Africa) countries showed a direct relationship between number of patents granted and GDP of BRICS [12]. The study led to the conclusion that increase in patenting activities amongst BRICS is an important factor for economic growth in these countries. Patent databases such as Patentscope from World Intellectual Property Organisation (WIPO), Espacenet for the European Patent Office (EPO) and the USPTO for the United States Patent and Trademark Office are used to extract the patent 
data (grants/registration) from which suitable indicators are derived. Other databases such as the Derwent World Patents Index (DWPI) can also be used if the priority areas and countries under consideration receive sufficient coverage; this database is particularly useful for citation analysis.

WIPO's Patentscope was used in this study; an advantage of this database is that it provides wide coverage of patents for South Africa and comparable countries of interests. It provides access to all International Patent Cooperation Treaty (PCT) applications in full text format on the day of publication, as well as to patent documents of participating national and regional patent offices of which BRICS countries are part. Additionally, this database allows for searching using keywords, names of applicants, IPC classes and sub-classes as well as other search criteria. Since the aim is to search for patents by inventors from each of the countries in any jurisdiction across the world this was an ideal database for this purpose. The analysis of patents provided answers the following two related research questions about South African research for each area:

1. What is the status of South Africa in technological development in each of the selected priority area? In this case, the study considers inventive activity through patent profile for each of the research areas.

2. What is the performance of South Africa in comparison to other BRICS countries (Brazil, Russia, India \& China), and compared to Egypt? Egypt is included in the study on the basis that it is the second most productive country in Africa in terms of research outputs as measured by publications and patents $[13,14]$.

The research aims to add to the literature on application of patent data as analytical tool in assessment of research advancement with emphasis on developing countries. Suitable indicators and statistics were computed and incorporated to add value to the patent data.

\section{Literature review}

\subsection{Review on patents and indicators in general}

Analysis of patents is done for various purposes from a legal and inventor purposes including establishing prior art where determining the novelty of a patent is a prime concern. Otherwise, organisations may analyse patents for different reasons such as determining patenting trends, forecasting technologies in particular domain, identifying technology competitors and determining technological vacuums and hot spots [15]. Various tools for doing this are available 
to extract the relevant patents from the various databases including automated tools. The authors distinguish between text mining techniques and visualisation approaches. The most commonly used patent repositories are the USPTO, EPO and the Japan Patent Office (JPO) [15].

While patent data does not provide complete picture of innovation developments in a field; a lot of information can be harvested from patents: for example the inventor, the office in which the patent is registered the claims, the technological field(s) under which a patent falls and more importantly the country of residence for the inventor(s). Based on this we consider briefly how to retrieve patents for a specific field from a database and important considerations for such a search. It is often pointed out that the most natural way to search for any document is to use keywords. However, for patents the use of keywords has its limitations, such as the fact that many companies use very unspecific vocabulary in order to make the scope of their patents as broad as possible [16]. Based on these limitations sometimes the use of International Patent Classification (IPC) system, which is used in 189 countries, is more appropriate. The IPC divides technology into eight sections, in turn, each section is divided into classes and classes further divided into subclasses and subclasses into groups resulting in approximately 70,000 subdivisions. Each subdivision has a symbol consisting of Arabic numerals and letters of the Latin alphabet [17]. The IPC system is particularly critical for the retrieval of patent documents in the search for "prior art." Prior art refers to any indication that an invention is already known, it does not necessarily have to exist physically or be commercially available. Patent-issuing authorities, potential inventors, research and development units need such information, this includes others concerned with the application or development of technology. In this article, the use of both the keyword and the IPC classification system is made for the search depending on the relevance for each of the technology areas under study.

Some emerging multidisciplinary research areas, which are of interest for human development such as nanotechnology and climate change, have received social tagging, making it easier to search for patents relating to the technology area. The areas that have received social tagging are not usable for small countries like South Africa as the EPO only uses this "social tagging" for states that produce at least a certain minimum number of patents. This implies that South Africa does not really receive coverage by the patent offices simply because it is patenting less than the minimum threshold. This complicated the search for the patenting trends in these multidisciplinary areas of research, making it necessary to go to the basics search methodologies using the patent classes or keywords for these areas. 
Various indices are used in patent analysis depending on the purpose of the study. Some of the indices that can be used in patent analysis are technology share (TS), technology leadership (TL) technology impact (TI) technology market impact TM [18, 19]. Another common indicator is the $R \& D$ efficiency, a ratio of patent output to the $R \& D$ expenditure for example Thomas, Sharma \& Jain [20] used R\&D efficiency ratio of patents granted to the R\&D expenditure to compare the 50 states of the USA. The R\&D efficiency is a very useful indicator particularly for comparing performance of different entities be it firms, countries or states within a country especially where accurate data on expenditures freely available. However, in cases where the study involves different technology fields, comparison of number of patents across different technology fields may be misleading, as different disciplines have different patenting patterns. The patents indicators are computed form the bibliographical data of patents including the IPC codes, priority numbers/dates/country, and inventor information such as address and other related data [21]. Additional approaches are claim based indicators such as the once described in the recent article [22], other approaches will be patent citation analysis and using the citation data to map technology areas and the linkages between science and technology $[23,24]$. Other indicators are the technology cycle time (TCT), science linkage (SL) which consider the time it takes for the patent to be referenced in other patents. A useful indicator in such a case may be the revealed technology advantage (RTA) sometimes called a specialisation index. According to the OECD, the revealed technology advantage index provides an indication of the relative specialisation of a given country in selected technological domains and is based on patent application field. This indicator is related to the revealed comparative advantage index, which measures specialisation in economics as first described by Balassa [25]. It is defined as the country's share of patents in a particular technology field divided by the country's share of patents in all fields. The RTA is zero when the country holds no patent in a given sector, is equal to 1 if the country's share in the sector equals the country's share in all fields (no specialisation) and above 1 when a positive specialisation is observed. This important since these are priority areas and specialisation is expected over time.

Technological specialisation as measured by RTA is a useful tool for comparing across different countries and different technological areas. This indicator has been applied and used for the comparison of different regions, countries and technological areas [26, 27]. Technology specialisation shifts from country to country according to underlying technological competencies. Vertova (1999) [27] points out that in the $18^{\text {th }}$ century when the railways 
technology was taking off, the UK was the world leader whereas at the turn of the century Germany during the chemical industry. In the information, communications and technology era, Japan seems to be dominant. Additionally, RTA and patents share, both presented in this study, are the most useful of specialisation indicator in studies for the determination of the country's development stage, especially if a comparison is made for different technology areas [27].

National oriented policy makers make use of science and technology indicators based on patent data. However, it is particularly difficult to compare patents, as there are some shortcomings, which were also identified by the OECD [21], these include:

- A high presence of product patents compared to process patents

- Differing patent laws and procedure across regions

- Patents do not reflect any economic value

- Differences in patent behaviours across industries, technology fields and sectors

The fact that there is a time lag between the application for a patent and the grant also presents another set of challenges. In the case of the EPO and the USPTO, a patent application is usually published within 18 months of application [21]. However, the use of patents has its own unique set of advantages including the availability of patent data and very detailed information dating back several decades within the databases. In terms of technology development, publications and the patent are outputs from research and development and useful inputs of to the technology innovation measure the early stages of development. There are arguments that patent data is a direct measure of invention activity and is not really a direct measure of technological innovation or innovation activity. However, cumulative invention can be used as a proxy for technology innovation. The rate of growth can be used as a proxy for collective accumulative technological capability or socioeconomic competence [21].

\subsection{Patenting in South Africa and other developing countries}

In a developing country such as South Africa, inventors tend to prefer to file their most promising patents in foreign jurisdictions such as the United States through the USPTO or Europe using the EPO. This is most likely due to fact that South Africa for an example has a non-examining patent office, which has its disadvantages. In such a system, the responsibility for ensuring the validity of the application resides with the applicant [28]. This means that Companies and Intellectual Property Registration Office (CIPRO), now called Companies and 
Intellectual Property Commission (CIPC), does not investigate the novelty or inventive merit of the invention meaning that only the forms or documentation are verified and not the substance of the product or process. This is a major departure from the international norm in developed countries where the applicant is required to prove that the invention has some function, is novel and not obvious to a person skilled in that field. South Africa therefore does not have examiners to safeguard the quality of invention it registers. This creates certain undesirable market behavior such as broadening the scope of the patent, multinationals applying and being granted patents that would not be granted in their home countries. This makes South African system one of the cheapest in the world with the resultant proliferation of frivolous patents and exploitations by foreign interests [28]. This is no different from other developing countries in general, a similar trend was found for an example in Malaysia. A certain study looked at the developing countries with specific reference to Malaysia using that country's and the US patenting system and found that patenting activity is increasing with most of the patents coming from foreign firms in that country as is the case in South Africa [29].

Due to the fact that very little is known about innovative activities in the developing countries, in this study, an attempt to examine the inventive activities of a developing economy in particular South Africa is done. Deorsola et al; [30] on the review found that the BRICS have very differing intellectual property frameworks. The other BRICS such as China, India, Russia and Brazil have examining patent offices although it takes quite a long time to get a patent granted in Brazil because of the low number of patent examiners in its National Institute of Industrial Property (INPI). India through Intellectual Property India have a very well established patent system dating back to 19th century in the case of India. These patent jurisdictions, India and Brazil are also examining authorities. Russia modernised its intellectual property in 1996 and the patenting is managed through its Federal Service for Intellectual Property (Rospatent). If the inventive activity across the BRICS is compared, China is the most active in the field of patenting in general. The Chinese patent office called the State Intellectual Property Office (SIPO) issues the highest number of patents in the world with annual growth rates of more than $20 \%$ in patents for the last 15 years. One author [31] attributed the growth of patenting in China to increased FDI, increased research spending and favourable legislation such as the revision of Chinese patent law in 2000 . 


\section{Methodology}

The relevant patents were extracted using either the keyword or the relevant patent class in cases in which the technology area has clearly defined patent classes or subclasses. A patent is credited to a country if at least one of its authors is affiliated with an institution that has an address in that country. In the case of co-authored patents, each patent is credited to all countries that appear among the inventor's affiliations, that is whole counting. There is a lot of work that has been done to determine the difference in country rankings arrived at using four different counting methods (i.e. whole counting, straight counting, whole-normalized counting, and complete-normalized counting) in patent counts. The issue with fractional counting is that it is time consuming and requires that the contents of the patents be studied in detail to assign the correct fractional count to each inventor. This may not be necessary as a number of studies show that counting methods have only minor [32] to no effect [33] on country rankings in patent counts. This does not mean the fractional count methodology does not have its proponents and is indeed a valid methodology for such studies [34].

Biotechnology patents for example can be extracted from a number of relevant classes as recommended in the OECD framework [35]. Curran and Leker [36] have also used a suggested method for the extraction of ICT patents from different patent classes and subclasses. In the case of nanotechnology an attempt to use a new class referred to as the wildcard earlier that has been implemented was done. The implementation of the search was abandoned due to practical consideration of this class, keywords were used instead. For patents related to energy and health, the use of relevant keywords was made. The search terms or IPC class used are according to table 1 .. The table specifies the references of previous research which have utilised similar methodology. The health patents are measured by using a combination of pharmaceuticals and medical devices classes. Energy looked at all the classes that may encompass energy including renewable energy and energy efficiency. A method adapted from Popp [37] was used; this author used US patent classes. This was converted to relevant IPC classes using the USPC-to-IPC Concordance tables. The patent search was carried out using the WIPO's Patentscope, as this is the most representative for the countries under consideration. In addition, the user interface is quite well structured allowing for the use of both keywords and IPC classes, results can be further filtered by priority date, applicant country amongst others. It is worth noting that the classification of technology types has been an ongoing area of research and there are alternative methodology such as the one suggested by Schmoch [38]. 
The table below shows the strategy followed for the extraction of relevant patents in the fields under consideration. The strategies followed for the individual technology areas were dependent on the unique structure of the technology. In several cases, methodology from the OECD working groups on science and technology was used. The OECD has a credible system and working groups consisting of experts from each of the participating member and observer countries in each area of technology.

Table 1. List of priority areas that are considered in this study and the search strategy used to extract he patents.

\begin{tabular}{|c|c|c|}
\hline Area & Search strategy & Reference \\
\hline Nanotechnology & $\begin{array}{l}\text { Codes } \\
\text { Tag Y01N on EPO changed to B } 82 \text { Y } \\
\text { class } 977 \text { on USPTO or Keywords }\end{array}$ & $\begin{array}{l}{[39]} \\
\text { Or keywords as in } \\
{[40]}\end{array}$ \\
\hline Biotechnology & $\begin{array}{l}\text { IPC codes } \\
\text { A01H1/00,A01H4/00,A61K38/00,A61K39/00,A6 } \\
\text { 1K48/00,C02F3/34, C07G(11/00,13/00,15/00), } \\
\text { C07K(4/00,14/00,16/00,17/00,19/00), } \\
\text { C12M,C12N,C12P,C12Q,C12S,G01N27/327, } \\
\text { G01N33/(53*,54*,55*,57*,68,74,76,78,88,92) }\end{array}$ & $\begin{array}{l}{[41]} \\
{[42]} \\
{[35]}\end{array}$ \\
\hline ICT & $\begin{array}{l}\text { IPC Codes } \\
\mathrm{H} 04 \mathrm{M}, \mathrm{G} 06 \mathrm{C}, \mathrm{G} 10, \mathrm{G} 03 \mathrm{~B}, \mathrm{G} 01 \mathrm{C}\end{array}$ & {$[36]$} \\
\hline Energy & IPC codes & [37] \\
\hline Health & $\begin{array}{l}\text { IPC codes } \\
\text { A61 [B, C, D, F, G, H, J, L, M, N], H05G. and } \\
\text { A61K not A61K-008 }\end{array}$ & [43] \\
\hline
\end{tabular}

An exploratory search was conducted and the methodology was then optimised depending on what was obtained from that search. An exploratory search for example of nanotechnology using the special class B82 revealed very few patents. On close analysis this class does not cover chemical or biological nano-structures for example, provided for elsewhere these would be expected to make a huge percentage of total nanotechnology patents. A use of keywords based query as described by Maghreb, Abbasi, Amiri, Monsefi and Harati [40] revealed a more realistic picture on patent landscape. It is worth mentioning that an attempt was made to include space technology in the study using a methodology from the OECD [44]. However, an exploratory search under the relevant IPC class B64G (and some other classes such as G01S19) that represent patents in the Cosmonautics, Vehicles or Equipment described as apparatus for, or methods of, winning materials from extra-terrestrial sources revealed less than five patents worldwide by South African inventors over the period under review. This shows the relatively 
low level of patenting for this technology within the country; based on this space was abandoned as a subject of this study.

The reported patent counts are based on the priority date as per OECD recommendation, the inventor's address country and one unit is allocated to all co-inventors mentioned in each patent (no fractional counting). A patent granted in different jurisdictions, called a patent family, count as one patent for an inventor. Data was downloaded from the WIPO's database Patentscope during the month of August 2016. The search was carried out using all patent offices where a patent with at least one South African resident as an inventor are registered. The methodology did not discriminate between the examining and non-examining jurisdiction.

\section{Results}

In this study, data on patents for South Africa in each of the technical areas was extracted from the database, the data on patent numbers produced worldwide in each of the areas was also extracted to calculate the world share in each of the fields. The next step was to extract the data on patents produced by the different regions over the period of study also to calculate their share over this period. The percentage share data thus generated was used for the eventual calculation of the RTA.

\subsection{South Africa patenting profile}

Table 2 shows the top three leading organisations in South Africa in terms of patent output in the different focus areas. 
Table 2.The top three patenting organisations in each of the sectors in South Africa

\begin{tabular}{|c|c|c|c|c|c|c|c|c|c|}
\hline \multicolumn{2}{|c|}{ Nanotechnology } & \multicolumn{2}{|l|}{ Health } & \multicolumn{2}{|l|}{ ICT } & \multicolumn{2}{|l|}{ Energy } & \multicolumn{2}{|c|}{ Biotechnology } \\
\hline $\begin{array}{l}\text { Total } \\
\text { patents }\end{array}$ & 105 & $\begin{array}{l}\text { Total } \\
\text { patents }\end{array}$ & 269 & $\begin{array}{l}\text { Total } \\
\text { patents }\end{array}$ & 112 & $\begin{array}{l}\text { Total } \\
\text { patents }\end{array}$ & 580 & $\begin{array}{l}\text { Total } \\
\text { patents }\end{array}$ & 194 \\
\hline $\begin{array}{l}\text { Patenting } \\
\text { Organisa } \\
\text { tion }\end{array}$ & $\begin{array}{l}\text { Num } \\
\text { ber } \\
\text { of } \\
\text { paten } \\
\text { ts } \\
\end{array}$ & $\begin{array}{l}\text { Patenting } \\
\text { Organisat } \\
\text { ion }\end{array}$ & $\begin{array}{l}\text { Num } \\
\text { ber } \\
\text { of } \\
\text { paten } \\
\text { ts } \\
\end{array}$ & $\begin{array}{l}\text { Patenting } \\
\text { Organisa } \\
\text { tion }\end{array}$ & $\begin{array}{l}\text { Num } \\
\text { ber } \\
\text { of } \\
\text { paten } \\
\text { ts } \\
\end{array}$ & $\begin{array}{l}\text { Patenting } \\
\text { Organisa } \\
\text { tion }\end{array}$ & $\begin{array}{l}\text { Num } \\
\text { ber } \\
\text { of } \\
\text { paten } \\
\text { ts } \\
\end{array}$ & $\begin{array}{l}\text { Patenting } \\
\text { Organisa } \\
\text { tion }\end{array}$ & $\begin{array}{l}\text { Num } \\
\text { ber } \\
\text { of } \\
\text { paten } \\
\text { ts } \\
\end{array}$ \\
\hline $\begin{array}{l}\text { Element } \\
\text { Six } \\
\text { (South } \\
\text { Africa) }\end{array}$ & 25 & $\begin{array}{l}\text { University } \\
\text { of the } \\
\text { Witwaters } \\
\text { rand } \\
\text { (South } \\
\text { Africa) }\end{array}$ & 38 & $\begin{array}{l}\text { Kahn, Ari } \\
\text { (South } \\
\text { Africa) }\end{array}$ & 11 & $\begin{array}{l}\text { Sasol } \\
\text { Technolo } \\
\text { gy (South } \\
\text { Africa) }\end{array}$ & 91 & $\begin{array}{l}\text { Universit } \\
\text { y of Cape } \\
\text { Town } \\
\text { (South } \\
\text { Africa) }\end{array}$ & 21 \\
\hline $\begin{array}{l}\text { Council } \\
\text { for } \\
\text { Scientific } \\
\text { and } \\
\text { Industrial } \\
\text { Research } \\
\text { (South } \\
\text { Africa) }\end{array}$ & 8 & $\begin{array}{l}\text { University } \\
\text { of Cape } \\
\text { Town } \\
\text { (South } \\
\text { Africa) }\end{array}$ & 18 & $\begin{array}{l}\text { Telkom } \\
\text { (South } \\
\text { Africa) }\end{array}$ & 3 & $\begin{array}{l}\text { Element } \\
\text { Six } \\
\text { (South } \\
\text { Africa) }\end{array}$ & 9 & $\begin{array}{l}\text { Council } \\
\text { for } \\
\text { Scientific } \\
\text { and } \\
\text { Industrial } \\
\text { Research } \\
\text { (South } \\
\text { Africa) }\end{array}$ & 19 \\
\hline $\begin{array}{l}\text { PST } \\
\text { Sensors } \\
\text { (South } \\
\text { Africa) }\end{array}$ & 7 & $\begin{array}{l}\text { North } \\
\text { West } \\
\text { University } \\
\text { (South } \\
\text { Africa) }\end{array}$ & 11 & $\begin{array}{l}\text { U-MAN } \\
\text { Universal } \\
\text { Media } \\
\text { Access } \\
\text { Networks } \\
\text { (Germany } \\
\text { ) }\end{array}$ & 3 & $\begin{array}{l}\text { PetroSA } \\
\text { (South } \\
\text { Africa) }\end{array}$ & 8 & $\begin{array}{l}\text { Stellenbos } \\
\text { ch } \\
\text { Universit } \\
\text { y (South } \\
\text { Africa) }\end{array}$ & 15 \\
\hline
\end{tabular}

It was found that energy at 580 patents is an area of research with the highest number of patents followed by health at 269 patents then biotechnology and ICT while nanotechnology showed the lowest number of patents at 105 in various patenting offices worldwide. South African inventors produced a total of 105 patents in nanotechnology with Element Six the synthetic diamond producer, described earlier, producing the highest. Interestingly, PST Sensors, is a company founded by a professor from the University of Cape Town (UCT).

The area of health is also dominated by the universities with the University of Witwatersrand producing 38 patents out of a total of 269 patents. The university hosts the Wits Health Consortium (Pty) Limited, a wholly owned company that pursues entrepreneurial innovation in health and supports clinical trials. This university therefore is focusing to taking its research outputs beyond the laboratory. There is some participation of the multinationals in this field 
with companies like Bayer Healthcare, Adcock Ingrams and Unilever having some patents in this area, these are in low quantities.

In the case of ICT, a leading inventor is in fact an individual by the name Ari Kahn. This individual at some point collaborated with the Mobile Telephone Networks (MTN) as one of the patents is owned by the MTN. MTN is a South African mobile telephone service provider. Telkom and UMAN, a German software company each own three patents in this area. Telkom is a partially state-owned telephone company that provides mobile and fixed line telephone network. There is lower presence of universities and science councils in this sector with patents mostly granted to individuals and start-up companies.

The country produced a total of 580 patents in energy [Table 2]. In the area of energy, Sasol Technology produced a total of 91 patents making it the highest producer of patents in this area. Sasol Technology is a research and development subsidiary of the Sasol limited, a Johannesburg and New York Stock Exchange listed petrochemicals company famous for producing oil from coal through the company's proprietary Fischer-Tropsch process. This is followed by Element Six, a synthetic diamond and related technology company and a part of the De Beers group one of the world's biggest diamond producers. The synthetic diamonds and related materials are used for many industrial applications across a range of industries. On third place is PetroSA, which is the state owned petroleum company that mostly produces fuel and petrochemicals from natural gas. This is the only sectors that was found to be dominated by commercial companies in terms of patenting.

Biotechnology patenting is dominated by the universities and the government owned science councils with the UCT producing the most patents in this field producing 21 out of the total of 194 patents produced by inventors in this country. The university is consistently ranked among the top in terms of research output and this explains its leadership in the area of biotechnology. 


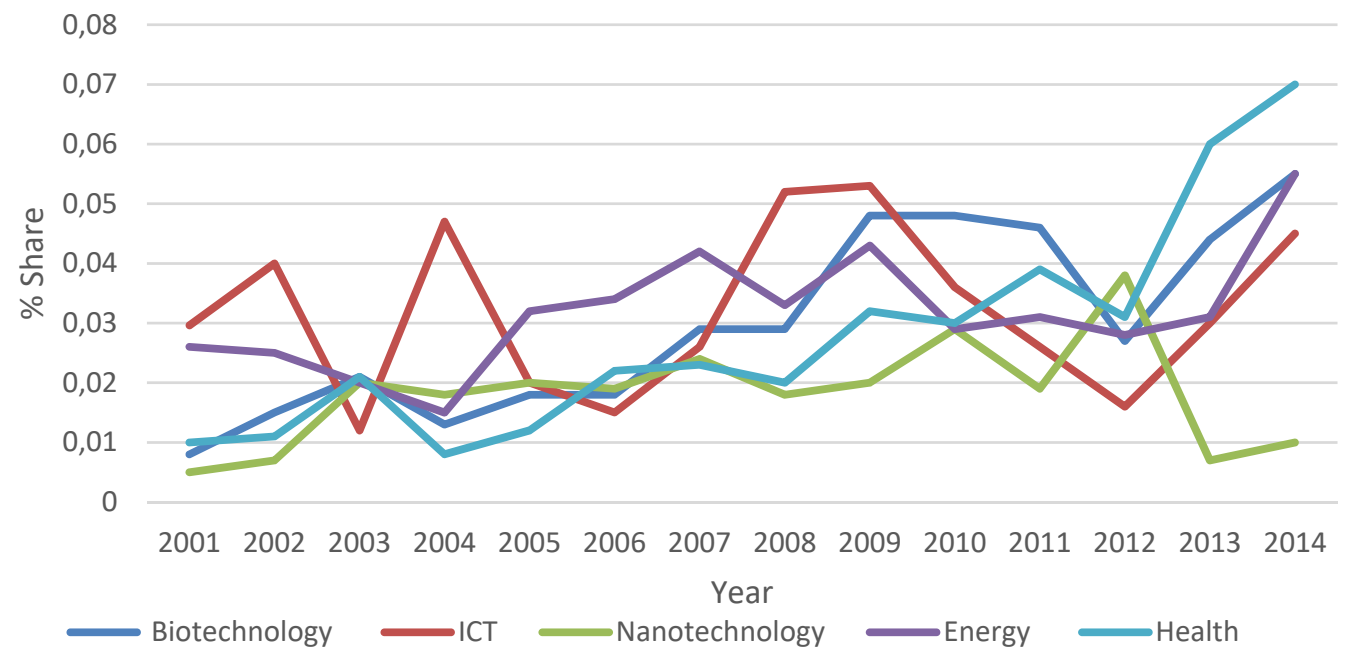

Figure 1. The percentage share of patents in different areas by South Africa from $2001-2014$

Figure 1 shows the percentage share of each of the priority areas compared to the total patents produced by inventors in the country. There is no clear trend, which demonstrate the lack of consistency within the areas examined in South Africa. In nanotechnology patents share for example was less than $0.01 \%$ in 2001 and in 2013 it is still less than $0.01 \%$. One notable exception is the patent share of health related patents that has increased from $0.01 \%$ in 2001 to on $0.07 \%$ in 2014 .

Table 3. The world share percentage of patents in different technologies for South Africa

\begin{tabular}{lrrrrr} 
Year & Biotechnology & \multicolumn{1}{l}{ ICT } & Nanotechnology & Energy & Health \\
\hline 2001 & 0.008 & 0.029 & 0.005 & 0.026 & 0.010 \\
2002 & 0.015 & 0.040 & 0.007 & 0.025 & 0.011 \\
2003 & 0.021 & 0.012 & 0.020 & 0.020 & 0.021 \\
2004 & 0.013 & 0.047 & 0.018 & 0.015 & 0.008 \\
2005 & 0.018 & 0.020 & 0.020 & 0.032 & 0.012 \\
2006 & 0.018 & 0.015 & 0.019 & 0.034 & 0.022 \\
2007 & 0.029 & 0.026 & 0.024 & 0.042 & 0.023 \\
2008 & 0.029 & 0.052 & 0.018 & 0.033 & 0.020 \\
2009 & 0.048 & 0.053 & 0.020 & 0.043 & 0.032 \\
2010 & 0.048 & 0.036 & 0.029 & 0.029 & 0.030 \\
2011 & 0.046 & 0.026 & 0.019 & 0.031 & 0.039 \\
2012 & 0.027 & 0.016 & 0.038 & 0.028 & 0.031 \\
2013 & 0.044 & 0.030 & 0.007 & 0.031 & 0.060 \\
2014 & 0.055 & 0.045 & 0.010 & 0.055 & 0.070 \\
$2005-2015$ & 0.029 & 0.032 & 0.018 & 0.032 & 0.023 \\
\hline
\end{tabular}


Table 3 shows the world share of patents in total for South Africa in each of the priority areas during the 2001 to 2015 period by various patenting offices. It is observed that in the areas of energy, ICT and biotechnology with a world share of $0.03 \%$, nanotechnology and health have almost the same world share at $0.02 \%$. It is clear that the latter two areas have been increasing their share unlike ICT and biotechnology.

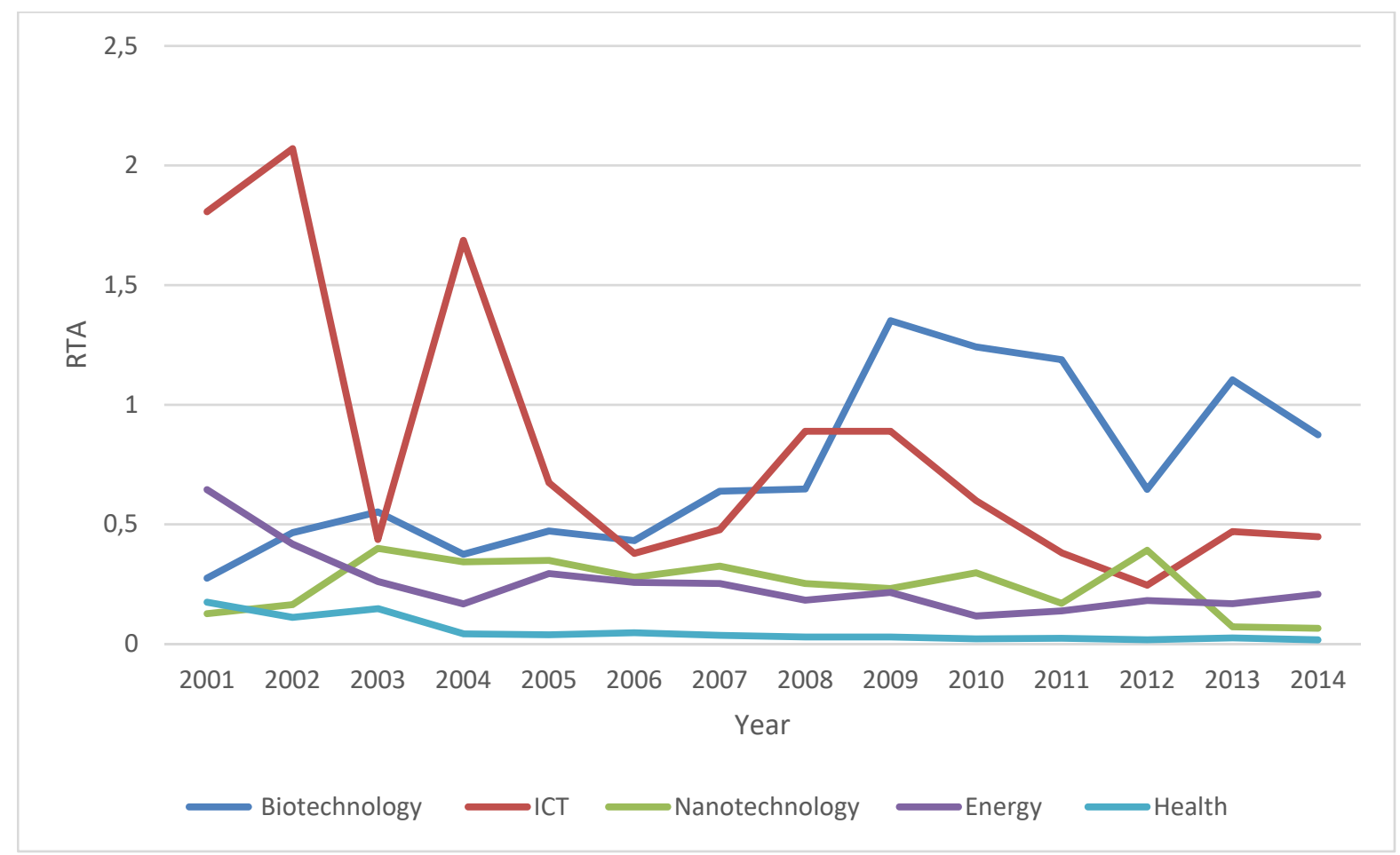

Figure 2. The specialisation indices for the research areas in South Africa from 2001 - 2014

Figure 2 shows the revealed technological advantage of each of the priority areas within South Africa.

The RTA was calculated from the statistics available from the patent data as obtained from Patentscope. Explicitly, percentage patents in the particular technology area is divided by the percentage patents in the world for that particular field, the data is available in the annexure. It is observed that in all areas except biotechnology for 2011 and 2013 as well as ICT in 2001 and 2004 year the values were significantly less than one indicating that the country has no technological advantage in each of these fields. Health when compared based on the RTA in general seems to be much worse off than all of the fields studied. Figure 2 indicates that the specialisation indices of all fields display quite similar trends with biotechnology showing a 
marked increase from a low base in 2001. Conversely, the index for the ICT area has been decreasing steadily from above 2 in 2002 to less than 0.5 in 2015. Nanotechnology, energy and in particular health research is really not doing well at all over this period as the index has been consistently low for the whole period under review.

4.2 Comparative analysis with the BRICS countries

Table 4. The world share percentage of overall patents for the BRIC countries

\begin{tabular}{crrrrrr}
\hline Year & $\begin{array}{c}\text { South } \\
\text { Africa }\end{array}$ & \multicolumn{1}{c}{ Brazil } & \multicolumn{1}{l}{ Russia } & \multicolumn{1}{l}{ India } & \multicolumn{1}{c}{ China } & Egypt \\
\hline 2001 & 0.032 & 0.016 & 0.043 & 0.040 & 0.062 & 0.0003 \\
2002 & 0.033 & 0.019 & 0.044 & 0.059 & 0.099 & 0.0015 \\
2003 & 0.038 & 0.026 & 0.049 & 0.078 & 0.141 & 0.0024 \\
2004 & 0.035 & 0.028 & 0.053 & 0.087 & 0.187 & 0.0023 \\
2005 & 0.038 & 0.030 & 0.057 & 0.111 & 0.314 & 0.0037 \\
2006 & 0.042 & 0.039 & 0.070 & 0.134 & 0.473 & 0.0025 \\
2007 & 0.045 & 0.054 & 0.075 & 0.165 & 0.624 & 0.0037 \\
2008 & 0.045 & 0.059 & 0.073 & 0.178 & 0.694 & 0.0039 \\
2009 & 0.035 & 0.059 & 0.086 & 0.199 & 1.073 & 0.0051 \\
2010 & 0.038 & 0.060 & 0.097 & 0.246 & 1.390 & 0.0042 \\
2011 & 0.039 & 0.069 & 0.109 & 0.224 & 1.645 & 0.0040 \\
2012 & 0.042 & 0.066 & 0.097 & 0.158 & 1.805 & 0.0041 \\
2013 & 0.040 & 0.064 & 0.096 & 0.181 & 2.349 & 0.0047 \\
2014 & 0.063 & 0.100 & 0.147 & 0.267 & 4.138 & 0.0072 \\
2015 & 0.056 & 0.092 & 0.077 & 0.299 & 4.523 & 0.0029 \\
$2005-2015$ & 0.039 & 0.045 & 0.073 & 0.1397 & 0.869 & 0.0032 \\
\hline
\end{tabular}

The table 4 details the percentage world share of patents for South Africa and each of the comparator countries. In terms of patents found on WIPO for each of the priority areas in the BRIC countries, results reveal that, as expected, China followed by India produce most patents with South Africa producing the least within this grouping of countries. It is important to note the magnitude of the Chinese output as they produce more patents than all the other BRICS member countries combined in all the areas being investigated.

When data was extracted on the total number of patents granted in each of the areas to inventors in each of the BRICS countries during the 2001 to 2015 period by various patenting offices. The results presented, according to the priority date, once again show that China followed by India produce most patents with South Africa producing the least. . In addition, China and India are growing their patenting activity quite aggressively as opposed to South Africa that has not 
grown the number of patents much during the period China, specifically, has been intensifying its efforts in patenting increasing is share from $0.06 \%$ in 2001 to $4 \%$.

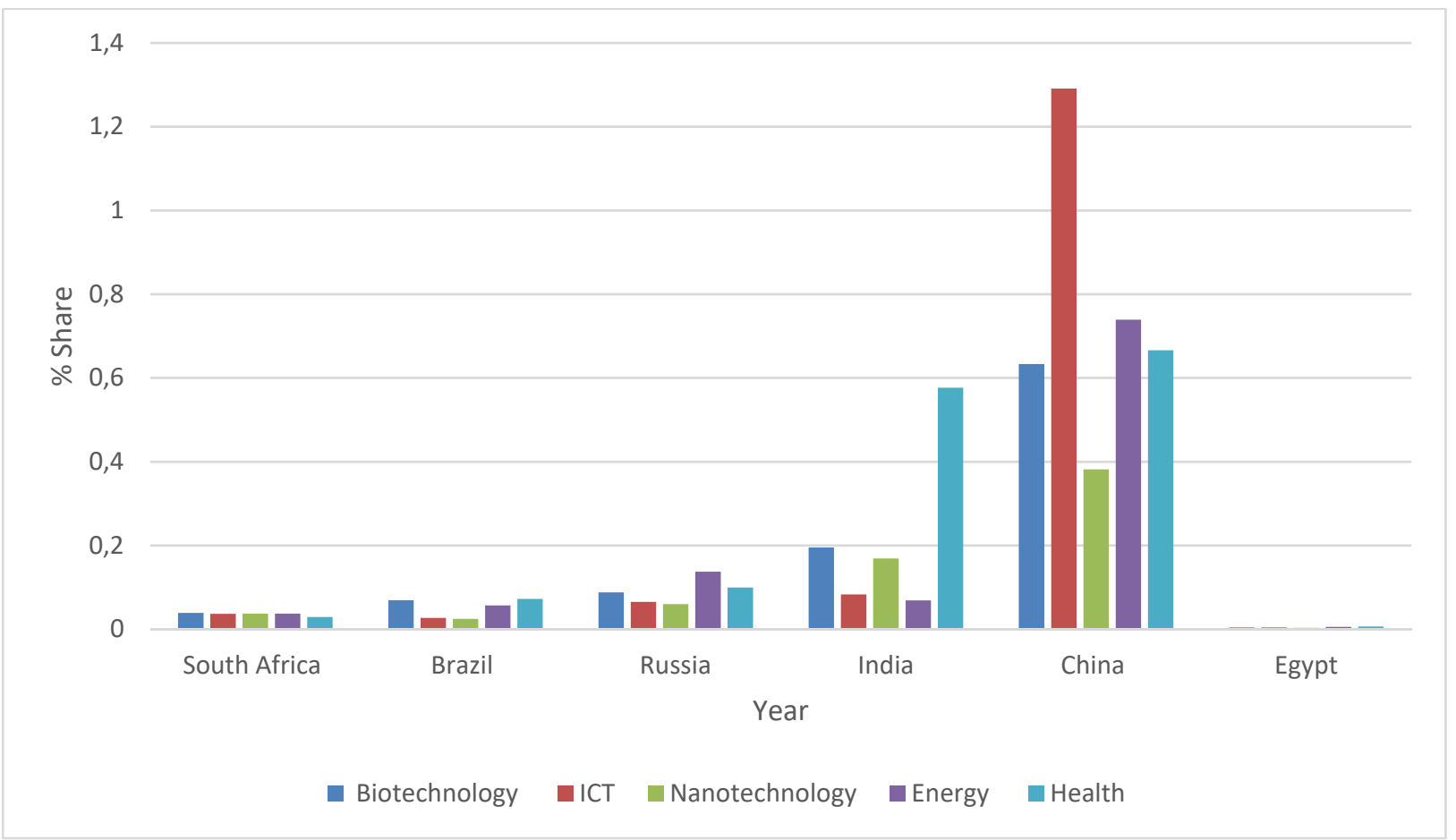

Figure 3. Patents percentage share in different areas per country cumulative from 2001-2015

Figure 3 shows the percentage share of patents in each field in each of the priority areas for South Africa and the comparator countries. It further demonstrates wide differences between the sizes of the innovation systems within the BRICS countries. In this case of patents share, China is a leading country followed by India with the two African countries having very little share of patents when compared to the worldwide production in this field. The share of South African patents for most areas is around $0.03 \%$ and notably South Africa has a higher share in nanotechnology than Brazil and Egypt. 


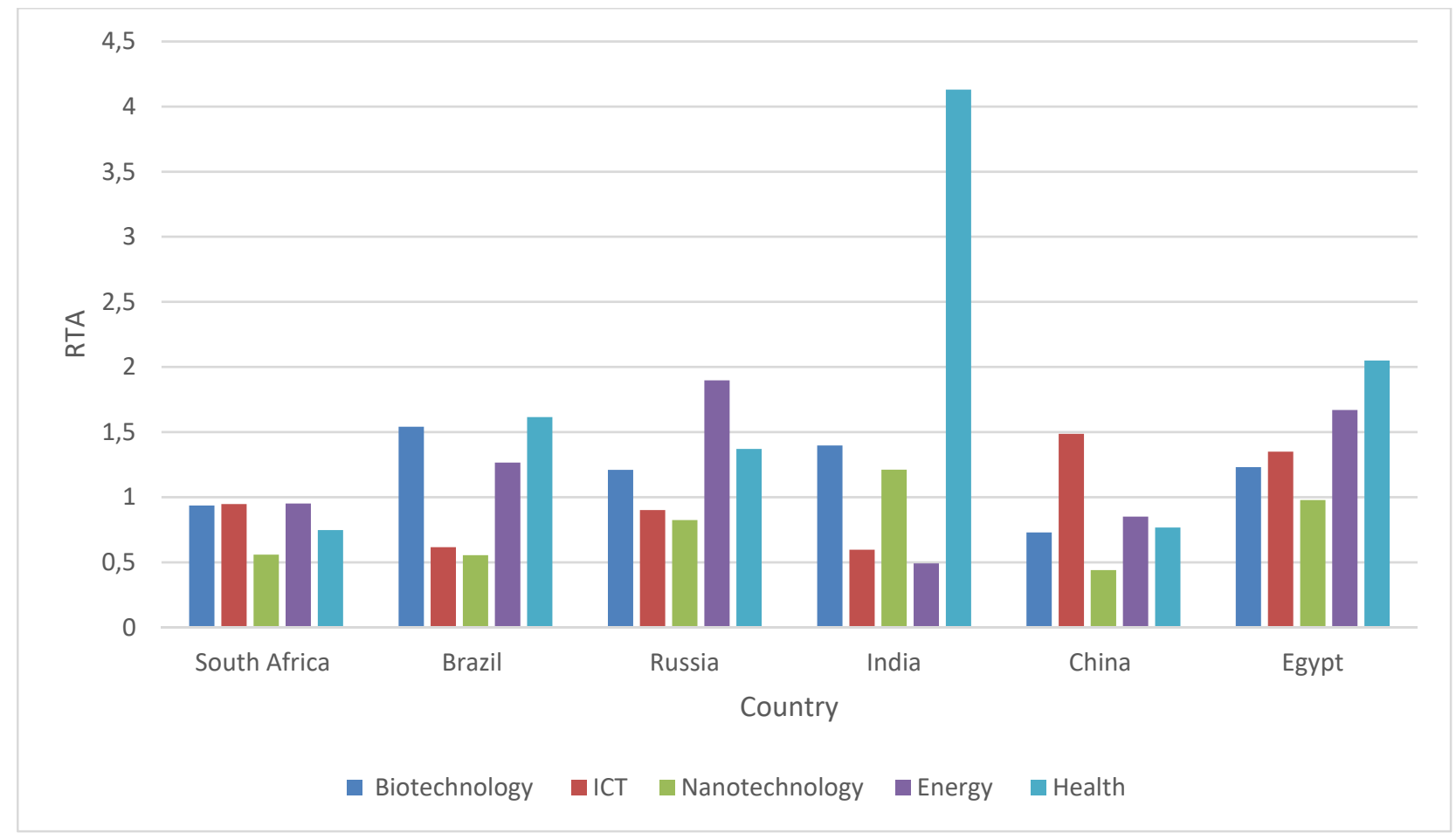

Figure 4. The specialisation indices in different areas per country cumulative from $2001-2015$

Revealed technological advantage for South Africa and each of the comparator countries is shown in the figure that follows (figure 4). The results show that while China tends to have a large share of patents worldwide the country's revealed technology advantage is much lower than those of other countries. India showed a big emphasis in the area of health with only the ICT and energy showing the value of less than 1, so there is specialisation in the areas of biotechnology, nanotechnology and health. While Egypt files relatively few patents each year, the areas examined show that the country specialises the area of health with an RTA of above 2, while ICT and biotechnology just above 1. On the contrary, South Africa has a larger share of patents but the emphasis and prioritisation is not in any of the fields studied, with all the values at less than 1 indicating no specialisation.

Figure 4 indicates that the specialisation indices of all fields display quite similar trends with India and to a lesser extent Egypt showing a marked specialisation in the areas of health over the period under review. Therefore, in terms of the RTA the performance of South Africa is comparable to that of the other BRICS countries. In addition, the two African countries considered in this study showed extremely low percentage share of output in all fields studied. The fact that the RTA is lower than 1 in all these priority areas shows that there is no higher 
emphasis of these technology application areas compared to general patent output in the country.

\section{Discussion and implications}

Looking at the patenting trend within the priority areas it is clear certain things are not working as expected. The level of patenting is very low, countries like South Africa and Egypt certainly have decent level of patent outputs in these fields, but this does not extend to patenting. The issue of patenting is problematic in the African continent with the lack of regional integration being a possible obstacle for inventors. The patenting systems regionally do not offer a onestop shop as in other regions leading to territorial patent laws [45]. This leads to very low level of patenting, for example, of the 2.5 million patents filed in 2013 only $0.6 \%$ were from African inventors. Clearly, there needs to be a more integration and processes need to be seamless between the patent offices.

There are some public policy implications that emerge because of the findings particularly for developing countries. It is clear that the South African inventors have not increased their patents substantially despite the introduction of the National Intellectual Property Management Office (NIPMO) and the enactment of the Intellectual Property Rights from Publicly Financed Research and Development Act [46] - it seems that very little has improved. The aim is to protect intellectual property and intellectual property rights that are created with public funds. Few policy interventions such as a stringent patent office will legitimise the CIPC and inventors are likely to approach it to register their inventions. Funding instruments can also emphasise and emphasise patenting in addition to publishing - that for example the Chinese government currently incentivises.

Interestingly, towards the end of the year 2017, South Africa's Department of Trade and Industry released the Draft Intellectual Property Policy of the Republic of South Africa [47]. This draft policy has several proposals in terms of changing the existing intellectual property regime. These amongst others include the introduction of substantive search and examination for patents, a critical improvement as it means all patents will be examined for their validity before registration, stimulating genuine innovation. The leveraging of flexibilities contained in the Agreement on Trade -Related Aspects of Intellectual Property Rights (TRIPS) to ensure that South Africa protects IP rights while simultaneously promoting public health, local 
manufacture, research and development, innovation, food security, environmental considerations, transfer of technology and broad socio-economic development. Other proposals are the creation of a system for protection for traditional knowledge that will safeguard misappropriation and exploitation, as well as promote further research and development into products and services based on traditional knowledge. These changes mark a major change in the approach of IP management and, once implemented, are bound to have positive effect in future.

\section{Conclusions}

The study considered patenting activity in selected number of research priority areas of South Africa. The research output of South Africa is compared to that of its peers in the BRIC grouping using relative indicator relative technological advantage or specialisation index. Findings of this study indicate that the government prioritisation of these areas has not translated to increased patenting activity in these areas and a lack of specialisation. Therefore, while the overall patenting trend in South Africa is positive this is not affecting the priority areas. The comparison with the other BRICS countries demonstrate that China and India are quite dominant in patenting based mostly on the differing sizes but clearly, there are some areas of research that these countries have prioritised with health receiving a higher priority in India for example.

South Africa has a relatively low patenting culture as evidence from results shows. There needs to be a focus on incentivising international patenting to move research from the lab towards the market as is the objectives of the government policies. According to the last available figures, which are from the 2013/14 period the GERD as a percentage of GDP for South Africa stood at $0.75 \%$, the BERD is $0.32 \%$, this low investment in general by the business in research, and development could be an explanation for the low level of patenting. To put this into perspective the average GERD as a percentage of GDP and BERD as a percentage of GDP for the OECD countries is $2.38 \%$ and $1.58 \%$ respectively.

The South African patent office known as the Companies and Intellectual Property Commission needs to be transformed and patents applications have to go through the examination to assess their substantive validity. An examination process is a proven method to ensure quality submissions go through the system and should be put in place with urgency accompanied by 
appropriate legislation. It is established that stronger patent protection leads to a higher tendency of industry to invest in innovation [48]. Therefore, relevant legislation in line with international best practice will encourage private sector to increase patenting activity. The government policy and funding for research alone may not be the most appropriate mechanism due to its indirect connection to technological innovation. It is the market pull that is likely to drive patenting, this and the capacity to deliver the product to the market, which is most efficiently done by private enterprise.

\section{References}

1. Tijssen, R.J.W. (2007). Africa's contribution to the worldwide research literature: New analytical perspectives, trends, and performance indicators. Scientometrics, 71(2), 303-327 DOI: $10.1007 / \mathrm{s} 11192-007-1658-3$

2. Tödtling, F., Trippl, M., (2005). One size fits all? Towards a differentiated regional Innovation policy approach. Research Policy, 34, 1203 - 1219.

DOI: 10.1016/j.respol.2005.01.018

3. Basberg, B.L. (1987), Patents and the measurement of technological change: a survey of the literature. Research Policy, 16, 131-141. DOI: 10.1016/0048-7333(87)90027-8

4. DST. (2008). Innovation Towards a Knowledge-based Economy-Ten-year Plan for South Africa 2008-2018. Department of Science and Technology. Pretoria. South Africa

5. DST. (2002). National research and development strategy of South Africa. Department of Science and Technology. Pretoria. South Africa

6. Quach,U., Thorsteinsdóttir, H., Renihan, J., Bhatt, A., von Aesch, Z.C., Peter A., Singer P.A. \& Daar A.D. (2006). Biotechnology patenting takes off in developing countries. International Journal of Biotechnology \& Biochemistry, 8(1/2), 43-59.

7. Rogers, M. (1998). “The definition and measurement of innovation,” Melbourne Institute of Applied Economic and Social Research, The University of Melbourne, Melbourne Institute Working Paper No. 10/98,

8. Aspden, H. (1983). Patent statistics as a measure of technological vitality. World Patent Information, 5,170 -173. DOI: 10.1016/0172-2190(83)90137-0

9. Abraham, B.P. \& Moitra, S.D. (2001). Innovation assessment through patent analysis. Technovation, 21, 245 -252. DOI: 10.1016/S0166-4972(00)00040-7 
10. Luan, C., \& Zhang, T., (2011). Innovation in China: a patentometric perspective (19852009). Journal of knowledge-based innovation in China, 3(3), 184-197.

DOI: $10.1108 / 17561411111167854$

11. Griliches, Z. (1990). Patent statistics as economic indicators. Journal of Economic Literature, 28(4), 1661- 1707.

12. Kumar, D., Singh, N., (2015), Patenting Trends among BRICS and Effect on GDP. Economic Affairs: A Quarterly Journal of Economic, 60(3), 473- 477. DOI:10.5958/09764666.2015.00067.4

13. Naravaez-Berthelemot, N. Russell, J.M. Arvanitis, R. Waast, R. Gaillard, J (2002).

Science in Africa: An overview of mainstream scientific output. Scientometrics, 54 (2), 229-241. DOI: 10.1023/A: 1016033528117

14. Pouris, A., \& Pouris, A. (2009). The state of science and technology in Africa (20002004): A scientometric assessment. Scientometrics, 79(2), 297-309 https://doi.org/10.1007/s11192-009-0419-X

15. Abbas, A. Zhang, L and Khan, S.U., (2014). A literature review on the state-of-the-art in patent analysis. World Patent Information, 37, 3-13. DOI: 10.1016/j.wpi.2013.12.006

16. Eisinger, D., Tsatsaronis, G., Bundschus, M., Wieneke, U., \& Schroeder, M. (2013). Automated Patent Categorization and Guided Patent Search using IPC as Inspired by MeSH and PubMed. Journal of Biomedical Semantics, 4(1), 1-23. DOI: 10.1186/2041-1480-4-S1-S3.

17. World Intellectual Property Organization (WIPO). (2015). International Patent Classification. [http://www.wipo.int/classifications/ipc/en].

18. Ernst, H. (2003). Patent information for strategic technology management, World Patent Information, 25(3):233-242. DOI: 10.1016/S0172-2190(03)00077-2

19. Geum, Y. Lee, S. Yoon, B. Park, Y (2013). Identifying and evaluating strategic partners for collaborative R\&D: Index-based approach using patents and publications, Tec novation, 33(6-7), 211-224. DOI: 10.1016/j.technovation.2013.03.012

20. Thomas V.J., Sharma S., Jain, S.K., (2011). Using patents and publications to assess R\&D efficiency in the states of the USA. World Patent Information, 33(1), 4-10. DOI: 10.1016/j.wpi.2010.01.005

21. OECD (Organisation for Economic Cooperation and Development) (1994). The Measurement of Scientific and Technological Activities, Using Patent Data as Science and Technology Indicators - Patent Manual. OECD, Paris. 28. OECD. (2005). A framework for biotechnology statistics. OECD, Paris 
22. Tijssen, R.J., (2001). Global and domestic utilization of industrial relevant science: patent citation analysis of science-technology interactions and knowledge flows. Research Policy, 30(1), 35-54 DOI: https://doi.org/10.1016/S0048-7333(99)00080-3

23. van Raan, A.F., (2017). Patent citations analysis and its value in research evaluation: A review and a new approach to map technology-relevant research. Journal of Data and Information Science, 2(1), pp.13-50, DOI: https://doi.org/10.1515/jdis-2017-0002

24. Milanez, D.H., de Faria, L.I.L., do Amaral, R.M., Gregolin, J.A.R., (2017). Claim-based patent indicators: A novel approach to analyze patent content and monitor technological advances, World Patent Information, 50, 64-72, DOI: https://doi.org/10.1016/j.wpi.2017.08.008

25. Balassa, B., (1965), Trade Liberalization and "Revealed' Comparative Advantage. The

Manchester School of Economic and Social Studies, 33, 99-123.

DOI:10.1111/j.1467-9957.1965.tb00050.x

26. Khramova, E., Meissner, D. and Sagieva, G., (2013). Statistical Patent Analysis Indicators as a Means of Determining Country Technological Specialisation. Higher School of Economics Research Paper No. WP BRP 09/STI/2013. DOI: http://dx.doi.org/10.2139/ssrn.2247936

28. Pouris A, Pouris A. (2011). Patents and economic development in South Africa: Managing intellectual property rights. South African Journal of Science. 107(11/12), 1-10. DOI:10.4102/sajs. V107i11/12.35524.

29. Govindaraju, V.G.R.C. \& Wong, C.Y., (2011). Patenting activities by developing countries: The case of Malaysia. World Patent Information, 33(1), 51-57. DOI: 10.1016/j.wpi.2010.01.001

30. Deorsola, A.B., Martins Ribeiro Leal, M. C., Cavalcante, M.D, Schmidt, I.J. Braga, E.J. (2017). Intellectual property and trademark legal framework in BRICS countries: A comparative study. World Patent Information, 49, 1- 9. DOI: 10.1016/j.wpi.2017.03.001

31. Zhang, H. (2010). What is behind the recent surge in patenting in China? International Journal of Business and Management, 5(10), 83-91

32. Zheng, J., Zhao, Z., Zhang, X. Huang M, Chen D., (2014). Influences of counting methods on country rankings: a perspective from patent analysis. Scientometrics. 98(3), 2087-2102. https://doi.org/10.1007/s11192-013-1139-9

33. Elango, B. \& Rajendran P., (2017). Whole counting vs. whole-normalized counting: A country level comparative study of internationally collaborated papers on Tribology. 
International Journal of Information Dissemination and Technology. 7(2). 123-127.DOI: 10.5958/2249-5576.2017.00010.3.

34. Huang, M.H., Lin, C.S. and Chen, D.Z., (2011). Counting methods, country rank changes, and counting inflation in the assessment of national research productivity and impact. Journal of the Association for Information Science and Technology, 62(12), pp.2427-2436 DOI https://doi.org/10.1002/asi.21625

35. OECD. (2005). A framework for biotechnology statistics. OECD, Paris

36. Curran, C. S., \& Leker, J. (2011). Patent indicators for monitoring convergence-examples from NFF and ICT. Technological Forecasting and Social Change, 78(2), 256-273 DOI: 10.1016/j.techfore.2010.06.021

37. Popp, D. (2002). Induced innovation and energy prices. The American Economic Review, 92(1), 160-180. DOI: 10.1257/000282802760015658

38. Schmoch, U. (2008). Concept of a technology classification for country comparison. Final report to the World Intellectual Property Organization (WIPO). Retrieved from: http://www.wipo.int/edocs/mdocs/classifications/en/ipc ce 41/ipc ce 41 5-annex1.pdf.

39. Igami, M. and Okazaki, T. (2007). Capturing Nanotechnology's current state of development via analysis of patents STI Working Paper 2007/4. OECD. Paris DOI: $10.1787 / 168778071481$

40. Maghreb, M., Abbasi, A., Amiri, S., Monsefi, R., Harati, A., (2011). A collective and abridged lexical query for delineation of nanotechnology publications. Scientometrics, 86, 15 -25. DOI: 10.1007/s11192-010-0304-7

41. Chen, Z., \& Guan, J. (2011). Mapping of biotechnology patents of China from 19952008. Scientometrics, 88(1), 73-89 DOI: 10.1007/s11192-011-0380-3

42. Arts, S., Appio, F. P., \& Van Looy, B. (2013). Inventions shaping technological trajectories: Do existing patent indicators provide a comprehensive picture? Scientometrics, 97(2), 397-491 DOI: 10.1007/s11192-013-1045-1

43. OECD (2009), "Health-related patents", in OECD Science, Technology and Industry Scoreboard 2009, OECD. Paris. DOI: 10.1787/sti_scoreboard-2009-22-en 44. OECD (2011), The Space Economy at a Glance 2011, OECD Publishing. Paris. DOI: $10.1787 / 9789264111790$-en

45. Sayagues, M. (2015). Africa's inventors shackled by bad IP regimes, Appropriate Technology, 42(3), 34 - 35.

46. South Africa (2008). Property Rights from Publicly Financed Research and Development Act, 2008. Pretoria. Government Printers 
47. South Africa (2017). Draft Intellectual Property Policy of the Republic of South Africa.

Government Printers. Pretoria. Accessed from

https://www.gov.za/sites/default/files/41064_gen636.pdf date of access 20 December 2017

48. Allred, B.B. Park, W. G. (2007). The influence of patent protection on firm innovation investment in manufacturing industries. Journal of International Management, 13 (2), 91 109. DOI: $10.1016 /$ j.intman.2007.02.001 